\title{
DEN NYA KVINNAN BEHÖVER DEN NYE MANNEN.
}

\author{
KONSTRUKTION AV MANLIGA IDENTITETER I \\ FRU MARIANNE AV VICTORIA BENEDICTSSON \\ OCH DOTTER TILL EN DOTTER AV INGER \\ ALFVÉN
}

\author{
KATARZYNA SZYMONIAK \\ Adam Mickiewicz University in Poznań
}

ABSTRACT. The purpose of this paper is to problematize and compare the construction of masculine identity in two Swedish novels, Fru Marianne (1887) by Victoria Benedictsson and Dotter till en dotter (1977) by Inger Alfvén. The analysis is focused on how the male characters in these novels are constructed in the light of masculinity studies. In order to do that two types of masculine identity are considered: the New Man and hegemonic man. In both novels a change of the masculine identity pattern from the hegemonic masculinity towards the identity of the New Man can be observed, even though this process is performed differently. In the construction of male protagonists both authors refer to the same materialistic and symbolic attributes, however, these attributes are valued differently and play a different role in construction of masculine identity. In construction of the masculine identity Benedictsson combines the attributes of the New Man with the positive features of the hegemonic man, whereas Alfvén rejects the hegemonic masculinity as oppressive and constructs the male protagonist as the New Man.

\section{INLEDNING}

I början av 1900-talet utfärdade författaren Elisabeth Dauthendey ett manifest i sin bok Ny kärlek. En bok för mogna andar (1902), i vilket hon tillkännagav den nya kvinnans inträde i samhället. Den nya kvinnan stod för förvandling av könsroller och det sociala kontraktet och var ett resultat av omfattande sociala förändringar som skedde vid tiden runt förra sekelskiftet (Lindén 2002:106). Förvisso påverkade dessa förändringar framförallt 
kvinnans ställning i det svenska samhället, men man kan inte förbise faktum att de också influerade män och var avgörande för det sättet på vilket könsidentiteter konstruerades under 1900-talet. Det kan därför konstateras att förändringen av kvinnoidealet skulle även ha fört med sig förvandling av mannen, men Dauthendey betonar att "mannen af i dag" inte hinner ifatt kvinnan, utan "han är ännu kvar hos kvinnan från i går och finner sig allra bäst hos henne" (Dauthendey 1902:5). Den nya kvinnan var ett fenomen som mannen inte kunde vara likgiltig för, utan "måste förhålla sig till, parera i en eller annan form" (Holm 1990:57). Ebba Witt-Brattström beskriver i Dekadensens kön det förra sekelskiftet som "den period då män tvingades definiera sig i förhållande till kvinnor och inte tvärtom" (Witt-Brattström 2007:10), vilket visar hur omfattande de förändringar som skedde i samhället var. Den nya kvinnan ställde krav på mannen.

Ur ett litteratursociologiskt perspektiv kan man betrakta litteratur som socialt fenomen och medium som avspeglar de företeelser som sker i samhället (Svedjedahl 1996). När man började upptäcka kvinnolitteratur på nytt med feministisk litteraturforskning som verktygslåda, koncentrerade man sig framförallt på hur den kvinnliga identiteten skapas, formas och tolkas i litteraturen. Däremot hamnade det litterära porträttet av den manliga identiteten i skymundan trots att den var ett verksamt verktyg som kvinnliga författare använde sig av för att förmedla sina idéer. I denna artikel problematiserar jag därför konstruktion av manlig indentitet i Fru Marianne (1887) av Victoria Benedictsson ${ }^{1}$ och Dotter till en dotter (1977) av Inger Alfvén. I synnerhet vill jag betona förändringen av det manliga identitetsmönstret från den hegemoniske till den nye mannen samt jämföra de sätt som de manliga gestalterna konstrueras på i texterna.

\section{TEORETISK UTGÅNGSPUNKT}

Undersökningen av konstruktionen av den manliga identiteten i de två valda texterna bygger på forskning om sociala representationer av kvinnlighet och manlighet ur maskulinitetsforskningsperspektiv ${ }^{2}$ med den hegemoniska maskuliniteten och den nye mannen som centralbegrepp. Den hegemoniska maskuliniteten är ett begrepp myntat av R.W. Connell som i Masculinities argumenterar att maskuliniteter inte tillhör någon självklar kategori som inte behöver definieras utan att de skapas genom kvinnors och mäns praktik och måste därför analyseras i interaktion med sådana kategorier som klass, ras, etnicitet och sexualitet (Connell 1995:71). Med detta intersektionella

\footnotetext{
${ }^{1}$ Benedictsson skrev romanen under pseudonymen Ernst Ahlgren.

${ }^{2}$ Maskulinitetsforskning är ett forskningsfält som problematiserar maskulinitet och uppmärksammar dess konstruktion, mångfaldighet och föränderlighet.
} 
perspektiv betonar hon att man inte kan tala om en maskulinitet, utan om maskuliniteter, vilket är utgångspunkt till urskiljning av tre typer av maskuliniteter: den hegemoniska maskuliniteten, den delaktiga maskuliniteten och den underordnade maskuliniteten.

Den hegemoniska maskuliniteten bygger på mannens dominans och kvinnans underordning och den kännetecknas av mannens auktoritet samt makten att påverka samhällets utformning och de värderingar som utgör samhällsnormen (Connell 1995:77, Johansson 2000:38-39). Den hegemoniska maskuliniteten är ett föränderligt och kulturellt konstruerat ideal som enskilda män inte alltid lever upp till och som därför kan betraktas som fantombild (Lindgren 1999:102). Den hegemoniska maskuliniteten hänger ihop med det traditionella genussystemet som enligt Yvonne Hirdman vilar på två principer: det dikotomiska isärhållandet av det manliga och det kvinnliga samt könshierarkin som medför att mannen betraktas som den norm kvinnan relateras till (Hirdman 1997:404-406). För att förstå hur könshierarkin upprätthålls i genussystemet måste man hänvisa till det symboliska våldet, ett begrepp myntat av Pierre Bourdieu som analyserat de dolda strukturer som tillerkänner männen företräde i nästan alla aspekter av livet. Bourdieu konstaterar att männens makt i samhället legitimeras just med det osynliga våldet som utövas t.ex. via kommunikation, kunskap, erkännande och känslor (Bourdieu 1999:11). Detta våld leder till att kategorier och dominansstrukturer konstrueras ur den dominerandes perspektiv och reproduceras både av enskilda agenter (t.ex. männen) och institutioner (t.ex. familj, staten) samtidigt som de erkänns både av den dominerande och den dominerade. Detta erkännande leder i sin tur till att dominansstrukturerna inte framstår som förtryck, utan som en naturlig ordning som inte ifrågasätts (Bourdieu 1999:48).

Bourdieu menar att männen tillerkänns större värde i samhället, men man måste betona att alla män inte tillerkänns lika högt värde. Den hegemoniska maskuliniteten värderas högre både i relation till kvinnor och till andra män som representerar de övriga maskulinitetstyper som Connell samlar under kategorier den delaktiga maskuliniteten och den underordnade maskuliniteten ${ }^{3}$. Det är viktigt både att uppmärksamma olika maskulinitetstyper och att betona relationer mellan dem (Connell 1995:81).

Mot bilden av den hegemoniska maskuliniteten kontrasterar en bild av den nye mannen som är ett annat centralbegrepp i min analys. Den nye mannen är ett fenomen som kan betraktas som en manlig motsvarighet till den nya kvinnan och begreppet förändrade sin betydelse under 1900-talet. Den nye

${ }^{3}$ Den delaktiga maskuliniteten innebär att männen utnytjar de privilegier som den hegemoniska maktpositionen för med sig samtidigt som de förhandlar med de kvinnor och de män som de lever med (Johansson 2000:29). Den underordnande maskuliniteten är ett paradigm som omfattar män som överskrider gränsen mellan det kvinnliga och det manliga och som därför betraktas som icke-manliga (Johnasson 2001:39). 
mannen som träder fram ur Dauthendeys manifest i början av 1900-talet är en man som betraktar kvinnan som en jämlik partner både i det intellektuella och moraliska avseendet (Dauthendey 1902:83). Han bejakar kvinnans intellektuella potential och istället för att behandla henne som ett viljelöst objekt, ser hennes rika själsliv. Dauthendey påpekar att mannen också måste vara "ren i kärleken" (Dauthendey 1902:83), vilket tyder på att den nye mannen förväntas uppfylla samma moraliska krav som ställs på kvinnan och vilket är ett viktigt steg på väg mot jämställdhet.

Betydelsen av begreppet den nye mannen skiftade under 1960-talet när könsrollsteorin gav upphov till förändring av det traditionella mansidealet som ansågs vara destruktivt. Det anses ha begränsat mannen och hindrat hans utveckling som en hel person (Klinth 1999:268). Mannen uppmuntrades därför att hämta sina karaktärsdrag både från "kvinnorollen" och "mansrollen" (Hill 2007:121), vilket ledde till att han skulle våga vara känslig och visa sina känslor. I centrum satte han inte längre karriären, utan förvandlades från den familjeförsörjande, men frånvarande far till pappa som inte bara hade en bra kontakt med sina barn, utan också tog större ansvar för hushållsarbete (Hill 2007:123).

Den nya kvinnan och den nye mannen som förekom i det svenska samhället under 1900-talet avspeglades ofta i kvinnolitteraturen. De litterära identitetskonstruktionerna av den nya kvinnan och den nye mannen tycks vara hopvävda och ömsesidigt beroende, vilket leder till att kvinnans förändring under 1900-talet som avspeglades i litteraturen förde med sig även förändring av den litterära mansbilden.

\section{MATERIAL}

Textanalysen bygger på Benedictssons och Alfvéns numera klassiska kvinnoromaner. Fru Marianne skildrar äktenskapet mellan stadsflickan Marianne och lantbrukaren Börje. I början är äktenskapet olyckligt på grund av kvinnans uppfostran och makarnas skilda bakgrunder. Längtande efter estetiska upplevelser förälskar sig Marianne i Börjes barndomsvän, Pål, men deras förbindelse upphör när kvinnan upptäcker att hon väntar Börjes barn. Detta leder till att hon mognar, medan Pål tvingas resa bort. Mariannes bekännelse om relationen till Pål leder till den äktenskapliga krisen, men makarna återförenas i kamratskap och ömsesidig respekt när kvinnan förvandlats från dagdrömmare till en arbetsam hustru och god moder.

Eva-Marie, huvudpersonen i Dotter till en dotter, är en välutbildad och självförsörjande kvinna som arbetar som kurator på ett sjukhus. Hon är gift med Andro som hon älskar ovillkorligt, men som visar sig vara opålitlig. Mannen är protestsångare på väg mot sitt genombrott, men trots att han sjunger samhällskritiska visor, lever han kvar i en bekväm mansroll där han 
ompysslas och försörjs av kvinnan. I takt med Eva-Maries förändring, växer hennes missnöje och beskvikelse på mannen. Romanens vändpunkt är hennes beslut att bryta sig ut ur sitt ojämställda äktenskap efter att ha upptäckt att underordningen under mannen är ett mönster som hon har ärvt ner efter sin mor och mormor.

Både Benedictsson och Alfvén räknas till de mest framstående kvinnliga författarna och de båda sätter kvinnoproblematik i fokus, bl.a. förändring av kvinnans relation till mannen, vilket $\mathrm{i}$ sin tur påverkar konstruktion av den manliga identiteten. Samtidigt är romanerna intressanta att jämföra eftersom de skrevs i olika socio-historiska kontexter: Benedictssons bok kom ut innan den första vågens feminism var fullbordad, medan Alfvén författade sin bok $\mathrm{i}$ kölvattnet av den andra vågens feminism.

\section{MANSBILDER I FRU MARIANNE OCH DOTTER TILL EN DOTTER}

Marta Ronne gör i sin analys av kvinnoskildringar i litteraturen ett intressant påpekande om könsidentiteterna som enligt henne ofta ställs i motsatsförhållande till varandra och att kategorin "män" ofta utgör en negativ motbild till kategorin "kvinnor" (Ronne 2007:52). På vilket sätt konstruerar Benedictsson och Alfvén den manliga identiteten och hur skildrar de dess förändring? Kan maskulinitetesforskning kasta ett nytt ljus över konstruktion av den manliga identiteten i romanerna?

\subsection{BÖRJE: SEKELSKIFTETS ÖVERGÅNGSMAN}

I början av romanen framstår Börje som den man som uppfyller de krav som Dauthendey ställer på mannen i sitt litterära manifest. Det är en man som behandlar kvinnan som sin partner och "åt hvilken han kunnat förtro alla sina tankar" (Benedictsson 1887:68). Han bejakar hennes intellekt, fria vilja och integritet och därför tänker han inte utnyttja sin privilegierade position $\mathrm{i}$ samhället för att tvinga Marianne till giftermål, utan vill att kvinnan gifter sig med honom "af fri vilja, eller också alldeles inte!" (ibidem, s.6). På detta sätt avstår han från att betrakta kvinnan som ett viljelöst objekt utan bejakar hennes handlingsförmåga. Han vill inte ha någon "dockhemshustru", utan en mogen och arbetsam partner som är engagerad i gårdens angelägenheter. Att makarna inte kan skapa en jämställd relation trots Börjes moderna syn på kvinnan beror på Mariannes uppfostran och makarnas skilda bakgrunder. Som borgardotter har kvinnan uppfostrats till att vara ett föremål för mannens beundran och hennes liv består därför av estetisk njutning, romanläsning och

\footnotetext{
${ }^{4}$ Begreppet "dockhemshustru" hänvisar till en teaterpjäs av Henrik Ibsen "Et dukkehjem" (1879) som bl.a. tar upp kvinnans roll i äktenskapet.
} 
dagdrömmande. Hon är inte redo för den nye mannen som hon betraktar som ödmjuk och tafatt (ibidem, s.339). Hennes identitetskonstruktion kontrasterar mot den jordnära Börje, vars livsmening och livsglädje kommer från arbetet. Som den aktiva parten försöker mannen befria äktenskapet från denna "dockhemsprägel" genom att erbjuda kvinnan plats vid sin sida, uppmuntra henne till förvandling och försöka fästa hennes intresse vid arbetet. Det måste dock betonas att Börje inte tvingar kvinnan till förändring, utan ger med sig när han inser att hans försök att engagera kvinnan i gårdens affärer misslyckats.

Den manliga identiteten konstrueras i romanen som en föränderlig kategori. Efter att Marianne berättat för mannen om sin förbindelse med Pål, vilket också är romanens vändpunkt, förvandlas såväl mannen som kvinnans uppfattning om honom. Besviken inser Börje att Marianne är annorlunda än han tänkt sig och upptäcker att hon inte är värd att behandlas som partner. Han ångrar sig och bestämmer sig för att ändra sin inställning till kvinnan: "du skall inte gå och tro, att jag kan bli sådan jag har varit. Det blir jag aldrig mer. Jag har varit dum och godtrogen. Jag har varit en narr, som hvem som helst kunnat draga vid näsan. Derför blef frestelsen dig för stor" (ibidem, s.363-364). Börje går tillbaka till den hegemoniska maskuliniteten som ger honom känslan av makt och trygghet. Från den punkten förändras även berättartekniken som glider från den allvetande berättaren till täckt anföring som antar kvinnans perspektiv och gör det möjligt att följa mannens förändring utifrån hennes perspektiv.

Börjes hegemoniska identitet består av materiella och symboliska attribut som tyder på mannens makt och hans dominerande position. Ett exempel på de materiella attributen är den manliga kroppen som definieras i opposition till den kvinnliga kroppen. Förvisso är Börje mån om sitt utseende, men hans kropp estetiseras inte, till skillnad från den kvinnliga kroppen. Det är knappt möjligt för mannen att vara "föremål för beundran", vilket leder till att han inte kan objektifieras. I romanen nämns den manliga kroppen bara i samband med dess fysiska styrka som symboliserar en stark personlighet och ger därmed upphov till mannens symboliska makt. Med kvinnans blick skildras Börje som en man med "en rask bestämdhet $i$ hvarje hans rörelse, hans röst kunde höras på långt afstånd, men blef aldrig skrikig, det var någonting af väl afvägda krafter i allt hvad han tog sig till" (ibidem, s.338). Hans starka kropp associeras med trygghet, kraft och förnuft samt med dygder som viljestyrka och mod. Det är viktigt att påpeka att hans auktoritet grundar sig inte på den fysiska styrkan utan på hans personlighet:

Det slog henne plötsligt att det egentligen icke var den fysiska styrkan, som låg till grund för det intryck Börje gaf, utan det var någonting helt annat, någonting $\mathrm{i}$ ögonen, $\mathrm{i}$ sjelfva dragen (...). Hon kände sig med underlig makt fängslad av detta, som hon aldrig lärt sig förstå: hans individualitet. (...) 
Vid den snabba blick hon häftade på Börjes ansigte, då hon lyfte ögonen från hans hand, flög det genom hans sinne en instinktklik, eggande glädje, - kanske känslan af makt. (ibidem, s.349-350).

Förutom de materiella attributen uttrycks Börjes hegemoniska maskulinitet också genom symboliska attribut som t.ex. hans symboliska makt över kvinnan, vars kropp han betraktar som sin ägodel. Därför känns Mariannes uppträdande på balen i den utmanande klänningen för honom "som om man framdragit hans innersta känslolif till allmänhetens beskådande" (ibidem, s.64). Hans vilja att behålla Marianne för sig själv får honom vilja hänvisa henne till hemmets privata sfär och "hålla henne gömd (...) som en okänd princessa" (ibidem, s.132-133).

Arne Melberg argumenterar i sin analys av sexualpolitiken i Fru Marianne att mannens "styre är ett öppet patriarkat" (Melberg, 1980:59). Å ena sidan kan man instämma med Melbergs argumentation eftersom Marianne, som är inställd på att vinna Börje tillbaka, är redo för att göra det på hans villkor och därför utgör hon mannens befallningar "på pricken så, som han önskat" (Benedictsson 1887:367). Detta får henne att förvandlas i Börjes ögon till en duktig hustru som hittar sin plats i hans "arbetsmaskineri (...) styrdt af en enda vilja, - hans." (ibidem, s.372). Å andra sidan måste det betonas att Marianne accepterar mannens hegemoni medvetet och med ett bestämt mål i sikte, vilket Melberg inte tar hänsyn till. Hon tänker utnyttja mannens dominerande position för att vinna hans förtroende tillbaka och genom att göra sin man till viljes "skulle hon nå dit hon ville" (ibidem, s.368). Detta tyder på att kvinnan befriar sig från sin roll som ett viljelöst objekt och utnyttjar mannens hegemoni för att nå sina mål.

Konstruktion av Börjes identitet får ytterligare en vändpunkt när mannen märker sin frus förändring till en duktig hustru. Marianne befriar sig från sin gamla identitet som hennes uppfostran tvingade på henne och övergår från att leva i drömmen till att vakna upp till verklighet. "Klyftan är fyld" (ibidem, s.411) säger Börje och dessa ord markerar starten på makarnas nya förhållande som är byggt på gemenskap och kamratskap. Det är då som mannen som åter förvandlas till övergångsmannen åter vill att hans hustru skulle vara hans partner och kamrat, men den här gången är kvinnan redo för sin nya roll.

Ett viktigt element av konstruktion av mannens identitet som övergångsmannen är hans bejakande av kvinnans intellektuella och moraliska förmåga som gör henne värd att ta plats vid sin mans sida. Han framställs som ägare av det intellektuella kapitalet som Marianne efter sin "väckelse" till det nya "verkliga" livet saknar. Eva Heggestad pekar på mannens konstruktion som teacher-lover" och hans roll som "vägvisare ut i den världen som ligger utanför hemmet" (Heggestad 2003:66). Enligt henne konstrueras Börje som

${ }^{5}$ Teacher-lover är ett begrepp som skapades av Ellen Moers i Literary Women (1978). 
förmedlare, genom vilken Marianne kan skaffa sig kunskap om världen. Visserligen skulle man kunna tolka en sådan konstruktion av den manliga gestalten som upprätthållandet av den hegemoniska maskuliniteten, då mannen är kvinnans väg till kunskap, men Moers betonar att konstruktion av mannen som teacher-lover inte ska tolkas som ett uttryck för kvinnans undergivenhet, utan för hennes ambition att förbättras andligt och inte socialt genom kontakten med mannen (Moers 1978:156). Man bör också lägga märke till att Börje, som själv "har en obetvinglig vetgirighet" (Benedictsson 1887:415), erbjuder kvinnan plats vid sin sida och tänker inte ta position av en intellektuellt överlägsen som förkunnar uppenbara sanningar, utan som stimulerar kvinnan intellektuellt genom att uppmuntra henne att uttrycka sina tankar och åsikter. På detta sätt konstrueras han inte bara som Mariannes vägvisare, utan som hennes gelike i läroprocessen.

Konstruktion av Börjes identitet som övergångsmannen innebär utvidgning av den sfär som tillskrivs kvinnan. I början vill mannen gömma Marianne för världen, men i romanens slutfas vill han att kvinnan skulle ge sig $u t$ i världen med honom: "Vill du följa med - Marianne? Vill du dela med mig? Vill du vi ska' vara två om allting? Två att se och uppfatta och döma och läsa, två att hjelpa hvarandra i allt?” (ibidem, s.415). På detta sätt upphöjs kvinnans status av mannen och hon leds $u t u r$ den privata sfären och in i den offentliga sfär som ligger utanför hemmet.

Den manliga identiteten skapas som en utvecklingsprocess som genomförs i relation till den kvinnliga identiteten. I början presenteras Börje som den nye mannen som vill bryta med den manliga hegemonin i äktenskapet och erbjuder sin hustru en relation byggd på gemenskap. Men eftersom kvinnan inte är mogen nog för att skapa ett jämlikt förhållande, tvingas mannen att förändras till den hegemoniske mannen. Det måste påpekas att hans förvandling till den hegemoniske mannen är en viktig faktor som stimulerar kvinnans utveckling och förändrar hennes uppfattning om mannen. Med en ny blick tittar hon på Börje och börjar märka de dygder som den hegemoniska maskuliniteten associeras med i romanen och som blir mannens "positiva kapital". Kvinnan lägger märke till att "den Börje (...) var helt annorlunda än den ödmjuke, något taffatte tillbedjare, hon gift sig med" (ibidem, s.339) och erkänner att hon "kände sig dragen till honom i sitt inre" (ibidem, s. 339). I slutet av romanen förvandlas Börje åter till övergångsmannen som har en modern syn på kvinnan, men trots det betraktar Melberg honom som företrädare för patriarkatet och hävdar att det enda mannen kan erbjuda kvinnan är gemenskap och kamratskap som givetvis inte är jämställdhet, men som ändå är mera önskvärt för Marianne än den förnedrande ställning som hon hade i början av romanen (Melberg 1980:59). Förvisso kan man inte tala om jämställdhet i romanen i samma bemärkelse som man förstår den idag eftersom Börje inte kan förändra det sociala 
kontraktet som råder i samhället. Men det måste betonas att Benedictssons konstruktion av Börje som övergångsmannen som betraktar och behandlar sin fru som en jämlik partner samtidigt som han behåller den hegemoniska maskulinitetens positiva egenskaper är förnyande med tanke på den sociohistoriska kontext som romanen skapades i.

\subsection{ANDRO: FRÅN DEN HEGEMONISKE MOT DEN NYE MANNEN I MITTEN AV 1900-TALET}

Dotter till en dotter av Inger Alfvén är en roman som genomsyras av sin tids revolutionerande tankar, vilket gör konstruktion av den manliga identiteten inressant att analysera.

I början av romanen förefaller Andro som den moderne partnern till den kvinna som trädde fram under den andra vågens feminism. Andro och EvaMarie är eniga om att deras äktenskap ska basera på jämställdhet och kvinnan konstaterar att "jämlikheten i vårt förhållande hade varit självklar för oss båda. Den ingick så att säga i vårt äktenskapskontrakt." (Alfvén 1977:11). Men det visar sig snart att jämställdheten var självklar egentligen bara för kvinnan medan Andro reproducerar i sitt äktenskap den hegemoniska maktordningen enligt vilken han har uppfostrats. Under täcket av den falska jämställdheten, utnyttjar han de privilegier som den hegemoniska mansrollen innebär och kvinnan börjar inse att deras "förhållande byggde på hans villkor, hans behov hans önskningar" (ibidem, s. 181).

I likhet med Börje, grundar sig Andros hegemoniska maskulinitet både på materiella och symboliska attribut, men i Alfvéns roman har de en annan funktion. Till de viktigaste materiella attributen som konstituerar mannens könsidentitet hör den manliga kroppen som förknippas i romanen med sexualitet och sexuell förmåga. Detta tyder på sexualitetens väsentliga roll i konstruktion av den manliga identiteten, vilket är något som inte lyfts fram av Benedictsson. Alfvén konstruerar, på samma sätt som Benedictsson, den manliga kroppen som en motbild till den kvinnliga kroppen. Denna relation betonas i den dubbelstandard som gäller kroppens utseende och som innebär att den manliga kroppen varken estetiseras eller objektifieras. Medveten om sin mans objektifierande blick erkänner Eva-Marie att hennes "utseende betydde mycket för Andro" och lägger till: "Han skulle aldrig lagt märke till mej om jag varit ful, det hade han själv sagt. På det sättet hade män det lättare än kvinnor" (ibidem, s. 54). På många ställen i romanen beskrivs kvinnans försök att behaga mannen med sin kropp samt hennes rädsla för att bli lämnad om mannen upptäckte att hennes skönhet är förbi, medan samma standarder gäller inte Andro som själv struntar i att borsta tänderna eller tvätta håret då han vet att han duger som han är (ibidem, s. 14). 
Den manliga identiteten konstrueras i romanen som en motbild till den kvinnliga identiteten. Denna dikotomin baserar bl.a. på isärhållandet av det kvinnliga och det manliga och uttrycks exempelvis i att kvinnan belastas med serviceplikt som inte delas med mannen och som låter sig "passas upp som en självklar sak" (ibidem, s. 133). Samtidigt ger den upphov till den symboliska makten som är en av de viktigaste symboliska attributen som konstituerar den hegemoniska identiteten i romanen.

Den manliga och den kvinnliga identiteten utgör i romanen inte bara varandras motbilder, utan de också skapar en strukturell maktordning. Könshierarkin som placerar den manliga identiteten över den kvinnliga upprätthålls i romanen både av samhället och kvinnorna. Eva-Marie konstaterar att "vår status hämtade vi inte främst från vår lönegrad och titel utan från (...) vårt liv utanför jobbet som makor och mödrar med vackra hem, män i karriären och begåvade söner" (ibidem, s. 16). Männen i romanen tillerkänns värdighet $a$ priori, medan kvinnans sociala identitet knyts till den man hon har förhållande med, vilket betyder att hon värderas enligt sin mans symboliska kapital. Kvinnan erkänner också att det aldrig skulle ha fallit henne in att kritisera mannen (ibidem, s. 14), vilket tyder på att hon inte vågar ifrågasätta mannens dominerande position utan betraktar den som naturlig. Samtidigt pekar citatet på de identitetsmarkörer som konstituerar den hegemoniska identiteten i romanen: den maskulinitet som erkänns av samhället förknippas med sfären utanför hemmet, ekonomiska resurser, heterosexualitet, framgång och titlar som associeras med makten. Den manliga könsidentiteten kan därför tolkas som en kategori definierad av samhället, accepterad av kvinnor och formad genom interaktion mellan kön och andra kategorier som klass och den sexuella praktiken.

Förvisso förknippas den manliga identiteten med den symboliska makten, men det måste betonas att alla män inte får samma makt. Eva-Maries idealiserande uppfattning om sin man kontrasterar med faktum att Andro egentligen försöker utnyttja de privilegier som den hegemoniska maskuliniteten för med sig. Han kan egentligen inte leva upp till dess utmaningar, vilket får honom att uppträda som omanlig i samhällets ögon. Utan varken mål i livet eller fast inkomst betraktas han av omgivningen som ett "rötägg" som lever på sin fru och utnyttjar henne (ibidem, s. 12). Till synes verkar mannen ignorera samhällets omdöme om sig själv, men Eva-Marie ifrågasätter hans likgiltighet: "Jag visste inte om han brydde sej om att jag försörjt honom, om det kanske ändå kommit hans stolhet för när fast han jämt sagt motsatsen. (...) Vi hade båda slagit det ifrån oss, skrattat åt det, men ändå var jag inte säker på vad Andro kände" (ibidem, s. 59).

Hans omanlighet i samhällets ögon berövar honom dock inte makten över kvinnan som uttrycks t.ex. i att han undergräver hennes självkänsla, tillämpar dubbelmoral och förväntar sig att kvinnan alltid skulle anpassa sig till honom 
och hans planer, vilket skapar maktobalans i deras relation. Ett intressant exempel på mannens utövande av makt på kvinnan är hans konstruktion som Eva-Maries vägvisare i början av deras förhållande. Trots sin sämre utbildning är det Andro som visar henne världen, både i den metaforiska och bokstavliga meningen: "Andro brukade läsa högt för mej ur sina favoritböcker (...) och kommentera det han läste. Vi gjorde utflykter som var som äventyr för mej som aldrig kommit mej för med någonting" (ibidem, s. 13). Denna konstruktion av mannen utgör en parallell till konstruktion av Börje som "teacher-lover" i Fru Marianne, men det måste påpekas att den värderas annorlunda av Alfvén. Till skillnad från Benedictssons roman förutsätter teacher-lover relationen i Dotter till en dotter inte jämlikhet eftersom mannen inte vill föra diskussion med Eva-Marie, utan genom att vara inställd på att förkunna sina åsikter, passiviserar han kvinnan och bemäktigar sig position som intellektuellt överlägsen. Han tillskrivs kunskap och tolkningsförmåga som kvinnan, trots sin högre utbildning, anses sakna.

I romanen är den hegemoniska identiteten en kategori som, trots att den legitimeras av samhället och erkänns av kvinnor, visar sig genomgå en kris. När kvinnan bestämmer sig för att lämna Andro, bryter han ihop. Plötsligt förvandlas han till en osäker, osjälvständig och ångestfull man som genom gråt, bön och skrik försöker få kvinnan att stanna. Man kan konstatera att den kris som Andro upplever egentligen inte är någon kris av manligheten som kategori utan det är en kris av den hegemoniska maskuliniteten. Detta sammanbrott visar sig vara ett nödvändigt genombrott för Andro som börjar inse behov av sin förändring i riktningen mot den nye mannen. Hans omvandling omfattar revidering av hans relation till kvinnor och till andra män.

Förändringen av Andros relation till kvinnan innebär förändring av den dikotomiska och hierarkiska uppdelningen i det kvinnliga och det manliga. Den gamle Andro betraktade sig själv som begåvad och framgångsrik, medan han tittade ner på Eva-Maries arbete. Däremot är den nye Andro lyhörd och omhändertagande. Inte bara intresserar sig han för kvinnans angelägenheter och visar henne sitt stöd, utan vågar också visa och tala om sina känslor, vilket tidigare betraktade han som tabu.

Förändring av konstruktion av den manliga identiteten innebär att mannen måste inse det förtryck som den hegemoniska maskuliniteten utövar och ta avstånd från den. Därför är det nödvändigt att bryta sig ut ur den homosociala gemenskapen som innebär bl.a. att männen förväntas ta parti för andra män och som därför står i romanen för upprätthållandet av mannens dominerande position. Vid den ivriga diskussionen om fäder och mansrollen tar Andro avstånd från den manliga homosocialiteten och inför andra män erkänner att "antalet stora män är väsentligt mindre än vad de själva ofta tror" (ibidem, s. 271). Därmed ifrågasätter han inte bara mannens större värde som tillerkänns 
av samhället, utan bryter sig ut ur den manliga gemenskapen och genom att lägga armen runt sin fru visar henne sitt stöd.

I romanen är den manliga identiteten en komplex struktur som består av två mansbilder som är varandras motsatser: den nye och den hegemoniske mannen. Den första bilden, som träder fram ur Andros och Eva-Maries "äktenskapskontrakt", är en bild av den jämställde mannen, medan det andra mansidealet - den hegemoniska maskuliniteten - är den mansbild som dominerar i samhället $\mathrm{i}$ romanen. Trots att den döljs under den illusoriska jämställdheten, dekonstrueras den hegemoniska maskuliniteten i romanen både genom mannens handlingar och med kvinnans reflekterande blick. I romanen skildrar Alfvén mannens förändring från den hegemoniske till den nye mannen, vilket tyder på att den manliga identiteten konstrueras i romanen som en dynamisk kategori. Det är viktigt att påpeka att den hegemoniska maskuliniteten dekonstrueras i romanen inte bara som förtryckande för kvinnan, utan man betonar också dess begränsande inverkan på mannen.

\section{AVSLUTANDE DISKUSSION}

Trots att det ligger nästan ett sekel mellan Benedictssons och Alfvéns romaner, för konstruktioner av den manliga identiteten i de båda romanerna en dialog med varandra. I författarinnornas sätt att gestalta mannen kan man lägga märke både till likheter och skillnader. Den manliga identiteten konstrueras såväl av Benedictsson som Alfvén som en dynamisk utvecklingsprocess som sker i både relation till kvinnor och till män samt $i$ interaktion med kategorier som klass och sexuell praktik. Den manliga identiteten som träder fram ur romanerna är en föränderlig och mångfaldig kategori som konstrueras i motsatsförhållande till den kvinnliga identiteten.

Trots att både Benedictsson och Alfvén associeras med feministisk inriktning i litteratur, är deras strategier att konstruera den manliga identiteten olika. Den mannen som framträder i Fru Marianne är ett slags hybrid, "mannen-på-gränsen", som förenar i sig två mansbilder som verkar vara motstridande. Hans identitet konstrueras både av de egenskaper som är karaktäristiska för den nye mannen som Dauthendey skriver om och det positiva kapitalet som förknippas med den hegemoniska maskuliniteten. Det är en utopisk konstruktion av mannen som å ena sidan betraktar och behandlar kvinnan som sin partner, respekterar hennes integritet, men som samtidigt tydligt betonar sin manliga identitet som får honom uppträda som traditionellt manlig. Till skillnad från Benedictsson, betraktar Alfvén i sin roman den hegemoniska maskuliniteten och den typ av maskuliniteten som representeras av den nye mannen som oförenliga. Den mannen som Alfvén sätter upp som ett mål för män att uppnå är den nye mannen som accepterar kvinnan som jämställd partner, bejakar hennes intellektuella förmåga och tillgodoser hennes 
emotionella behov. Det är också en man som vågar ta avstånd från den manliga homosocialiteten och bejaka sin "mjuka", känsliga sida.

Att Benedictsson och Alfvén konstruerar sina manliga gestalter på olika sätt beror på deras olika omdöme om den hegemoniska maskuliniteten. Benedictsson betonar endast de positiva egenskaper som förbindas med mannens dominerande position, dvs. trygghet, flit och pliktkänsla, medan Alfvén markerar dess negativa egenskaper som förtryck, utnyttjande och dubbelmoral. Marta Ronne lägger $i$ sin analys av kvinnoskildringar i litteraturen märke till att kategorin "män" ofta får "negativt kapital" i litteraturen skrivna av kvinnor ett eftersom berättarens sympati tydligt ligger på kvinnans sida (Ronne 2007:52). Däremot är Benedictssons konstruktion av mannen positiv och hon ifrågasätter varken mannens symboliska makt eller det rådande genussystemet och anser att det inte är den hegemoniska maskuliniteten utan kvinnans uppfostran som hindrar jämställdhet. I romanen är det mannen som uppmuntrar kvinnan till förvandling från ett viljelöst objekt till ett handlande subjekt och på detta sätt blir han kvinnans medhjälpare i kampen för befrielse. Till skillnad från Benedictsson skildrar Alfvén den hegemoniska maskuliniteten entydigt som förtryckande för kvinnor och begränsande för män. Den hegemoniske Andro är bärare av det "negativa kapitalet" och istället för att vara kvinnans bundsförvant i kamp för befrielse skildras han som orsak till hennes underordnade position. Den enda möjligheten för mannen att befria sig från den destruktiva mansrollen är att utvecklas i riktningen mot den nye mannen.

I båda romaner är makten den viktigaste identitetsmarkör som konstituerar den hegemoniska mansidentiteten. Både Benedictsson och Alfvén pekar på könsdikotomins och könhierarkins roll för konstruktion av den manliga identiteten, men de värderas på olika sätt i romanerna. Benedictsson betraktar den tydliga uppdelningen i den manliga och den kvinnliga sfären som naturlig och anser att den både organiserar livet och ordnar konstruktioner av könsidentiteter genom att tydligt urskilja det manliga från det kvinnliga. Men framförallt ger den dikotomiska uppdelningen kvinnan möjlighet att få en jämställd plats vid mannens sida eftersom mannen betraktar kvinnan som sin partner endast i ett meningsfullt arbete. Däremot anser Alfvén den dikotomiska skillnaden mellan det manliga och det kvinnliga som orsak till maktobalansen, källan till kvinnans förtryckta position och begränsning för mannen. Det är märkvärdigt att det som hos Benedictsson symboliserar könens komplettering, föreställer Alfvén som ett fält för maktkamp.

"Mannen af idag är ännu kvar hos kvinnan från i går" - med dessa ord betonade Dauthendey i början av 1900-talet att även mannen måste förändras för att könen skulle kunna vara jämlika. Baserande på analysen av två romaner av kvinnliga författare, varav en skapades i slutet av 1800-talet och den andra i mitten av 1900-talet, kan man konstatera att även om mannen inte alltid hinner i fatt kvinnan, är han dock på väg. 


\title{
LITETRATURFÖRTECKNING
}

Alfvén, Inger. 1977. Dotter till en dotter. Stockholm: Bonniers.

[Benedictsson, Victoria] Ahlgren, Ernst. 1887. Fru Marianne. Stockholm: Hæggströms Förlagsexpedition.

Bourdieu, Pierre. 1999. Den manliga dominansen. Göteborg: Daidalos.

Connell, Robert William. 1995. Masculinities. Berkeley and Los Angeles: University of California Press.

Dauthendey, Elisabeth. 1902. Ny kärlek. En bok för mogna andar. Stockholm: Wahlström \& Widstrand.

Heggestad, Eva. 2003. En bättre och lyckligare värld: kvinnliga författares utopiska visioner 1850- 1950. Stockholm/Stenhag: Brutus Östlings Bokförlag Symposion.

Herz, Marcus \& Thomas Johansson. 2011. Maskuliniteter: kritik, tendenser, trender. Stockholm: Liber.

Hill, Helena. 2007. Befria mannen! Idéer om förtryck, frigörelse och förändring hos en svensk mansrörelse under 1970- och tidigt 1980-tal. Umeå: Text\&Kultur.

Hirdman, Yvonne. 1997. Genussystemet - reflexioner kring kvinnors sociala underordning. I: Fururland, Lars \& Johan Svedjedal (red.). Litteratursociologi. Texter om litteratur och samhälle. Lund: Studentlitteratur, s. 400-418.

Holm, Birgitta. 1990. Edith Södergran och den nya kvinnan. Tidskrift för litteraturvetenskap 1990:4, s. 57-64.

Johansson, Thomas. 2000. Det första könet? Mansforskning som reflexivt projekt. Lund: Studentlitteratur.

Klinth, Roger. 1999. Den emanciperade mannen. Mannen i familjen speglad genom utbildningsprogrammen i svensk radio och TV 1963-1971. I: Berggren, Anne Marie (red.). Manligt och omanligt $i$ ett historiskt perspektiv. Stockholm: Forskningsrådsnämnden, s. 257-274.

Lindén, Claudia. 2002. Om kärlek. Litteratur, sexualitet och politik hos Ellen Key. Stockholm/Stehag: Brutus Östlings Bokförlag Symposion.

Lindgren, Gerd. 1999. Klass, kön och kirurgi. Relationer bland vårdpersonal i organisationsförändringarnas spår. Malmö: Liber AB.

Lykke, Nina. 2003. Intersektionalitet - ett användbart begrepp för genusforskningen. Kvinnovetenskaplig tidskrift 2003:1, s. 47-56.

Melberg, Arne. 1980. Sexualpolitiken, Fru Marianne och En dåres försvarstal. Ord och Bild 1980:2-3, s. 50-65.

Moers, Ellen. 1986. Literary Women. London: The Women's Press.

Ronne, Marta. 2007. De Nya Människorna. Bilder av kvinnor och män hos mellankrigstidens kvinnliga förffatare. I: Ronne, Marta (red.). Mot normen. Kvinnors skrivande under 1900talet. Uppsala: Litteratur och samhälle Avd. för litteratursociologi, Uppsala universitet.

Svedjedahl, Johan. 1996. Det litteratursociologiska perspektivet. Om en forskningstradition och dess grundantaganden. Tidskrift för litteraturvetenskap 25:3/4, s. 3- 20.

Witt-Brattström, Ebba. 2007. Dekadensens kön. Stockholm:Norstedts.

\author{
Katarzyna Szymoniak \\ Uniwersytet im. Adama Mickiewicza w Poznaniu \\ Katedra Skandynawistyki \\ Collegium Novum \\ al. Niepodległości 4 \\ 61-874 Poznań \\ Poland \\ katszym@amu.edu.pl
}

